\title{
Consumer buying behaviour of fruit and vegetables in the Netherlands
}

\author{
Jassó, K. \\ Szent István Univeristy, Institute of Regional Economics and Rural Development
}

\begin{abstract}
Summary: The Dutch Households bought in 2010 compared with the year before a little less vegetables and less fruit. However because of a higher price level the supermarket sales of fruits and vegetables increased with $7 \%$ to almost $€ 3$ billion. A Dutch household bought 72.4 kilo fresh vegetables in 2010. This is $2 \%$ less than in 2009. Tomatoes are the most bought vegetable followed by onion and cucumber. Although the Dutch households bought less vegetables, the spending increased with 5\%. The average price of vegetables was $7 \%$ higher than in 2009 . In 2010 a Dutch household bought almost 88 kilo fresh fruit. Compared with 2009 this was $2 \%$ less. Apple is far out the most popular, followed by orange and banana. Also the spending on fruit decreased a little, specially on strawberry, kiwi and banana. The sales of vegetables is realized for almost $90 \%$ by the supermarket channel. Albert Heijn has a market share of 38\%, followed by Superunie and C1000. Also for fruit the supermarket is the most important retail channel. However fruit is also sold for $20 \%$ in grocery stores and markets. The total turnover from supermarkets of vegetables was in 2010 over $€ 2$ billion, $8 \%$ more than in $2009.85 \%$ of this is fresh product (fresh and pre-treated). Canned vegetables become less popular. The turnover was decreasing $2 \%$ to just under $€ 200$ million. Green beans are the most popular, followed by peas and carrots. However more money was spend on frozen vegetables $(+5 \%)$ and pickles $(+1 \%)$. Over $40 \%$ of the supermarket turnover of frozen vegetables is spend on spinach. The supermarket turnover of fruit increased in 2010 with $3 \%$ to $€ 1,25$ billion. From this $93 \%$ is fresh unprocessed fruit. The turnover of pre-treated (washed and sliced) is increasing, but still not more than $3 \%$. Although with a modest share, the spending on frozen fruit also increased in 2010 to $€ 5,5$ million. The turnover of canned fruit however was decreasing with $6 \%$ compared with 2009 . The supermarket turnover of pre-treated fruit was $€ 35$ million. Albert Heijn is the absolute market leader for pretreated fruit. In $201070 \%$ of the sales was realized by Albert Heijn. Mixed fresh pre-treated fruit, mainly fruit salads, account for $40 \%$ of the total supermarket turnover of processed fruit. Canned pineapple is the most important canned fruit in supermarkets, followed by fruit cocktail and peach. There is a high degree of awareness of consumers regarding the "must" to use enough fruit and vegetables. Despite of this, consumers do not always eat enough healthy products. Reasons for this are the busy life of the modern young people and the perception that vegetables are "not easy" to use. Therefore preparing a meal has to be easy and fast with suitable products Here is an important task for concept and product development.
\end{abstract}

Key words: Fruit, vegetables, household purchases, supermarket sales, consumer trends

\section{Introduction}

In the Netherlands the fruit and vegetable sector developed itself to an economic top sector, based on a long tradition with a high standard technology and well developed resources. Next to the production, the selling system of fruit and vegetables in Holland belongs to the most developed in the world. The traditional auction system for Dutch production made place for a modern high tech selling system with network of companies, where production from all over the world is traded. Naturally in the Dutch shops you will find a wide range of fresh fruit and vegetables of top quality. However in the modern fast world, consumers are continuously changing. The life of people becomes more busy. Next to work, people have an active social life where sports, hobbies or other activities are consuming all of their time so they have less time to cook. As a result preparing a meal has to be easy and fast with suitable products. Also people are travelling all over the world and eating habits of exotic countries are adopted into the Dutch kitchen. Governmental programs and campaigns stimulate specially young consumers to eat healthy and use more fruit and vegetables when preparing a meal.

Supermarkets have a big share in the sales of fruit and vegetables and this share is still growing. They have a wide range of products and they try to seduce the consumer to buy everything in the supermarket instead of going to other retail channels as grocery stores or markets. They provide consumers with recipes and are selling ready to use combinations.

To keep track of changing habits of consumers continues data is collected about the Dutch market for fresh fruits and vegetables. For this article I analysed the information from different sources. Reasons of changing consumer behaviour are important for retail channels to meet the consumer demands. I have used the results of my own qualitative research to make the right conclusions of trend analyses. 


\section{Material and methods}

In the past years the Dutch Government has stimulated in different ways a healthy lifestyle with fresh fruit and vegetable consumption. Therefore it is interesting to look at the developments and new trends in this sector. For this article I used three main sources of information:

The ConsumerScan from GFK. The market research agency GFK organizes a consumer panel with focus on Fast Moving Consumer Goods and fresh products. The consumer panel exists of 10.000 households which are representative for the total population in the Netherlands. The consumers are keeping record of what they are purchasing with an electronic bar-scanning device. Products without bar code can be scanned in a special code book. With this data trends can be detailed analyzed and reported.

The Retail Measurement Services from Nielsen. Nielsen collects data from a wide range of retail organizations. Nielsen measures sales volume, price, the effects of merchandising activities for own products and the products of competitors. With this data it is possible to determine market penetration of products, the sales in volume and value and market shares.

To get a better view of what people motivates in their behaviour towards the use of fruit and vegetables I have carried out a survey among consumers. The main aim for this quantitative research is to find out what the demands and expectation of the consumers are and which factors are of influence on the purchasing decision. The research gives answers on items like how the consumers habits are changing and how the new trends have influence on the consumers.

\section{Results}

\section{Household purchases of fresh fruit and vegetables}

In the past 3 years, the household purchases of fresh fruit and fresh vegetables has decreased. In 2010 Dutch households bought more than 1,18 billion kilogram of fresh fruit and vegetables. Compared to 2007 this means an decrease of $3 \%$. The table below shows the fresh fruit and vegetables purchases for the total Dutch population. The consumption of canned and frozen food is not taken into account in this table.

Table 1. Household purchases of fresh fruit and vegetables in the Netherlands $(\mathrm{kg} \times 1000)$

(Number of households: $2002=6.93$ million, $2007=7.22$ million, $2010=7.39$ million)

\begin{tabular}{lccc} 
& Vegetables & Fruit & Total \\
\hline 2002 & 500 & 654 & 1.154 \\
2007 & 532 & 688 & 1.220 \\
2010 & 535 & 649 & 1.184 \\
\hline $\mathbf{2 0 1 0 / 2 0 0 7}$ & $+\mathbf{1 \%}$ & $\mathbf{- 6 \%}$ & $\mathbf{- 3 \%}$ \\
\hline
\end{tabular}

Source: PT / GFK
Almost all the Dutch households are buying fresh vegetables. Based on the volume over $60 \%$ of the products are from the top 10 of most popular vegetables in the Netherlands. In the past 5 years the total purchases of vegetables was rather stable. Also the shares of the vegetables in the top did not change very much. Compared with 2006, especially the strong increase in household purchases of Stir-fry vegetables is remarkable. The Eastern way of preparing food by stir baking became much more popular. The purchase of paprika also shows a significant increase compared to 2006.

Table 2. Top 10 Domestic purchases of fresh vegetables (in $\mathrm{kg}$ per household)

\begin{tabular}{rlrrrrrr} 
& & $\mathbf{2 0 0 6}$ & $\mathbf{2 0 0 7}$ & $\mathbf{2 0 0 8}$ & $\mathbf{2 0 0 9}$ & $\mathbf{2 0 1 0}$ & $\begin{array}{c}\mathbf{2 0 1 0} \\
\mathbf{2 0 0 6}\end{array}$ \\
\hline 1 & Tomatoes & 6,86 & 6,57 & 6,64 & 7,13 & 6,87 & $0 \%$ \\
2 & Onions & 5,96 & 5,69 & 5,83 & 5,94 & 5,99 & $1 \%$ \\
\hline 3 & Cucumbers & 5,87 & 5,87 & 5,89 & 5,77 & 5,67 & $-3 \%$ \\
\hline 4 & Carrots & 5,47 & 5,17 & 5,25 & 5,01 & 5,11 & $-7 \%$ \\
\hline 5 & Lettuce & 5,01 & 4,99 & 4,57 & 4,68 & 4,64 & $-7 \%$ \\
\hline 6 & Cauliflower & 4,65 & 5,39 & 5,27 & 5,26 & 4,49 & $-3 \%$ \\
\hline 7 & Chicory & 4,06 & 4,01 & 4,20 & 4,20 & 4,12 & $1 \%$ \\
\hline 8 & Paprika & 2,56 & 2,42 & 2,64 & 2,92 & 2,89 & $13 \%$ \\
\hline 9 & Stir-fry veg. & 2,09 & 2,63 & 2,55 & 2,86 & 2,84 & $36 \%$ \\
\hline 10 & Broccoli & 2,79 & 2,80 & 2,81 & 3,10 & 2,82 & $1 \%$ \\
& Others & 27,94 & 27,63 & 26,79 & 27,13 & 26.98 & $-1 \%$ \\
\hline & Total & $\mathbf{7 3 , 2 6}$ & $\mathbf{7 3 , 1 7}$ & $\mathbf{7 2 , 4 4}$ & $\mathbf{7 4 , 0 0}$ & $\mathbf{7 2 , 4 2}$ & $\mathbf{- 1 \%}$ \\
\hline
\end{tabular}

Source: PT / GFK

The same analysis based on the value of sales shows a different picture. This is due to the large differences in the price per kilo of the various products and the different development in price during the past 5 years. Most remarkable are onions and carrots, in volume the second and fourth-best selling vegetables but based on spending at place nine and ten. Stir-fry vegetables are relative expensive. The increase of the spending of $42 \%$ compared to $36 \%$ in volume in the same period, shows that the Stir-fry vegetables became more expensive. Nevertheless this new way of preparing food has a strong growing popularity.

Table 3. Top 10 Domestic purchases fresh vegetables (in €per household)

\begin{tabular}{rlrrrrrr|} 
& & $\mathbf{2 0 0 6}$ & $\mathbf{2 0 0 7}$ & $\mathbf{2 0 0 8}$ & $\mathbf{2 0 0 9}$ & $\mathbf{2 0 1 0}$ & $\begin{array}{c}\mathbf{2 0 1 0} \\
\text { I }\end{array}$ \\
\hline 1 & Lettuce & 19,10 & 19,32 & 18,49 & 18,65 & 20,33 & $6 \%$ \\
\hline 2 & Tomatoes & 15,99 & 16,52 & 17,41 & 17,54 & 19,96 & $25 \%$ \\
\hline 3 & Stir-fry veg. & 8,02 & 10,22 & 10,16 & 11,46 & 11,41 & $42 \%$ \\
\hline 4 & Paprika & 8,79 & $\mathbf{9 , 3 8}$ & 9,40 & 9,04 & 10,25 & $17 \%$ \\
\hline 5 & Cucumbers & 10,07 & 10,04 & 9,59 & 9,00 & 9,64 & $-4 \%$ \\
\hline 6 & Mushrooms & 7,61 & 7,41 & 7,56 & 7,72 & 7,94 & $4 \%$ \\
\hline 7 & Green beans & 7,51 & 7,81 & 7,50 & 7,59 & 7,60 & $1 \%$ \\
\hline 8 & Chicory & 7,28 & 7,32 & 6,92 & 6,67 & 7,21 & $-1 \%$ \\
\hline 9 & Onions & 6,12 & 6,66 & 6,31 & 6,11 & 7,10 & $16 \%$ \\
\hline 10 & Carrots & 7,08 & 6,88 & 7,16 & 7,20 & 6,93 & $-2 \%$ \\
\hline & Others & 72,04 & 71,79 & 70,57 & 71,16 & 72,50 & $1 \%$ \\
\hline & Total & $\mathbf{1 6 9 , 6}$ & $\mathbf{1 7 3 , 3}$ & $\mathbf{1 7 1 , 1}$ & $\mathbf{1 7 2 , 1}$ & $\mathbf{1 8 0 , 9}$ & $\mathbf{7 \%}$ \\
\hline
\end{tabular}

Source: PT / GFK 
Almost all Dutch households are buying fresh fruit, only $1 \%$ indicated not to do this. However in the period from 2006 to 2010 the sales of fresh fruits in 2010 has decreased compared to 2006 with $8 \%$ in volume and $1 \%$ in turnover. Especially oranges, bananas and melons are bought less. The use of kiwi's and pears however increase in this period. The ranking does not really change from previous years.

Table 4. Top 10 Domestic purchases of fresh fruit (in $\mathrm{kg}$ per household)

\begin{tabular}{|c|c|c|c|c|c|c|c|}
\hline & & 2006 & 2007 & 2008 & 2009 & 2010 & $\begin{array}{c}2010 \\
/ \\
2006\end{array}$ \\
\hline 1 & Apples & 23,44 & 23,93 & 22,15 & 22,33 & 21,58 & $-8 \%$ \\
\hline 2 & Oranges & 20,63 & 20,37 & 18,37 & 17,41 & 17,14 & $-17 \%$ \\
\hline 3 & Bananas & 15,51 & 15,26 & 14,73 & 13,67 & 12,88 & $-17 \%$ \\
\hline 4 & Mandarines & 9,02 & 8,44 & 7,83 & 7,44 & 8,37 & $-7 \%$ \\
\hline 5 & Pears & 5,17 & 5,82 & 5,16 & 5,10 & 5,97 & $15 \%$ \\
\hline 6 & Grapes & 3,54 & 3,22 & 3,37 & 3,63 & 3,40 & $-4 \%$ \\
\hline 7 & Kiwi's & 2,69 & 3,17 & 3,29 & 3,44 & 3,10 & $15 \%$ \\
\hline 8 & Melons & 3,43 & 3,14 & 3,12 & 3,27 & 3,00 & $-13 \%$ \\
\hline 9 & Strawberries & 2,45 & 2,46 & 2,32 & 2,78 & 2,36 & $-4 \%$ \\
\hline \multirow[t]{3}{*}{10} & Nectarines & 1,91 & 1,59 & 1,47 & 2,07 & 1,82 & $-5 \%$ \\
\hline & Others & 8,08 & 8,17 & 7,75 & 7,98 & 8,14 & $1 \%$ \\
\hline & Total & 95,87 & 95,57 & 89,56 & 89,12 & 87,76 & $-8 \%$ \\
\hline
\end{tabular}

Source: PT / GFK

The sales value in table 5 shows a similar development. Also here the stable top three consisting of apple, orange and banana. Also the order of the rest of the top ten stays the same. Remarkable is on one side the decrease of the melons and nectarines and on the other side the increase of strawberries and kiwifruit. The increase of the turnover of the strawberries is caused by a price increase, while growth in kiwifruit is caused by an increase in sales volume.

Table 5. Top 10 Domestic purchases of fresh fruit (in €िer household)

\begin{tabular}{|c|c|c|c|c|c|c|c|}
\hline & & 2006 & 2007 & 2008 & 2009 & 2010 & $\begin{array}{c}2010 \\
/ \\
2006 \\
\end{array}$ \\
\hline 1 & Apples & 28,31 & 29,57 & 31,01 & 27,68 & 27,55 & $-3 \%$ \\
\hline 2 & Oranges & 23,37 & 23,28 & 22,02 & 20,02 & 20,53 & $-12 \%$ \\
\hline 3 & Bananas & 21,00 & 20,76 & 20,70 & 19,96 & 18,76 & $-11 \%$ \\
\hline 4 & Mandarines & 14,13 & 14,13 & 14,33 & 13,68 & 14,36 & $2 \%$ \\
\hline 5 & Grapes & 9,70 & 9,60 & 10,34 & 10,66 & 10,58 & $9 \%$ \\
\hline 6 & Strawberries & 8,90 & 9,81 & 10,10 & 11,57 & 10,45 & $17 \%$ \\
\hline 7 & Kiwi's & 7,09 & 8,12 & 9,23 & 8,88 & 8,17 & $15 \%$ \\
\hline 8 & Pears & 6,81 & 6,92 & 8,15 & 7,34 & 7,30 & $7 \%$ \\
\hline 9 & Melons & 4,72 & 3,96 & 4,02 & 3,86 & 3,77 & $-20 \%$ \\
\hline \multirow[t]{3}{*}{10} & Nectarines & 3,59 & 2,89 & 3,26 & 3,51 & 3,57 & $-1 \%$ \\
\hline & Others & 19,88 & 19,99 & 20,73 & 20,78 & 21,79 & $10 \%$ \\
\hline & Total & 147,5 & 149,0 & 153,9 & 147,9 & 146,8 & $-1 \%$ \\
\hline
\end{tabular}

Source: PT / GFK

\section{Supermarket sales of vegetables}

The supermarkets which are taken into account are divided into service supermarkets and discounters. Albert Heijn, Super de Boer and C1000 are service supermarkets, Aldi and Lidl are discounters and the Superunie is a group of shop formula's which include both groups. In this chapter, consumer purchases of fruit and vegetables in the period 2009-2010 is analyzed.
Table 6. Supermarket sales vegetables ( $€ \mathrm{x} 1000$ )

\begin{tabular}{lrrr} 
& $\mathbf{2 0 0 9}$ & $\mathbf{2 0 1 0}$ & $\mathbf{2 0 1 0 / 2 0 0 9}$ \\
\hline Fresh & 1.007 .249 & 1.117 .293 & $11 \%$ \\
Pre-treated & 594.279 & 631.158 & $6 \%$ \\
Canned & 201.374 & 197.216 & $-2 \%$ \\
Frozen & 64.372 & 67.906 & $5 \%$ \\
Pickles & 50.082 & 50.521 & $1 \%$ \\
\hline TOTAL & 1.917 .356 & 2.064 .094 & $8 \%$ \\
\hline
\end{tabular}

Source: PT / Nielsen

The Dutch supermarket sales of vegetables in 2010 was over $€ 2$ billion. The turnover increased with $8 \%$ compared with 2009. Consumers were spending $11 \%$ more on fresh unprocessed vegetables in supermarkets. Also the turnover of pre-treated (washed/cut) food increased with 6\%. The popularity of canned food is decreasing in the last years. The spending decreased with $2 \%$. Frozen food however is becoming more favourable. The spending increased with $5 \%$.

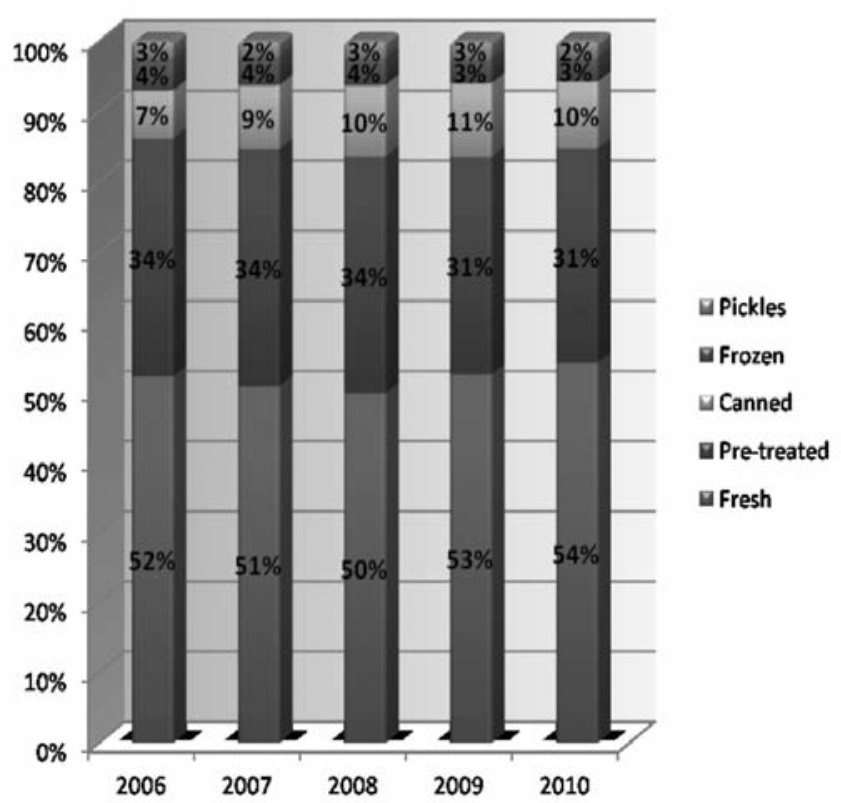

Figure 1. Supermarket Sales of vegetables (value) Source: PT / Nielsen

\section{Assortment vegetables supermarkets}

The supermarket is by far the most important retail channel for fresh vegetables and its share is still growing. The sales of vegetables in the supermarket in 2010 compared with 2009 is growing with $9 \%$ to $€ 1,75$ billion. In the same time sales by other retail channels is increasing $4 \%$. Albert Heijn is doing relatively well in sales of fresh vegetables, compared with other supermarkets. With an overall market share in retail of $30 \%$, Albert Heijn achieves a market share of $38 \%$ in sales of fresh vegetables through supermarket chains. Surprisingly Lidl is also doing quite well. The overall market share of Lidl is only half as large as Aldi, but Lidl sells more fresh vegetables. 


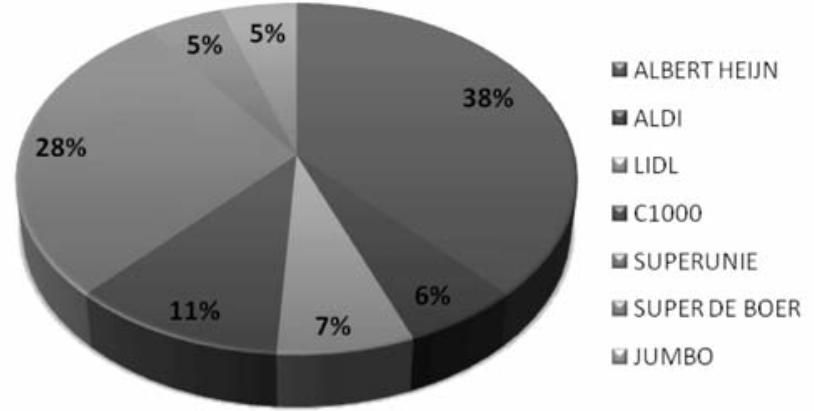

Figure 2. Supermarket Sales of fresh vegetables (value) Source: PT / Nielsen

\section{Pre-treated vegetables}

The Dutch supermarket sales of pre-treated vegetables increased with $6 \%$ to $€ 631$ million. Almost $30 \%$ of the supermarket sales of pre-treated fresh vegetables was achieved by the sales of lettuce. Specially the mixed lettuce, washed and cut in bags is booming business. Stir-fry vegetables follow with a share of $16 \%$. Also rapidly increasing is the sales of pre-treated string beans and kale with an increase of more than $10 \%$.

Table 7. Supermarket sales pre-treated fresh vegetables $(€ \times 1.000)$

\begin{tabular}{lrrr}
\hline & $\mathbf{2 0 0 9}$ & $\mathbf{2 0 1 0}$ & $\begin{array}{c}\mathbf{2 0 1 0} \\
\mathbf{2 0 0 9}\end{array}$ \\
\hline Lettuce & 168.300 & 179.533 & $7 \%$ \\
Stir-fry vegetables & 98.483 & 103.709 & $5 \%$ \\
\hline Soup vegetables & 34.808 & 37.007 & $6 \%$ \\
\hline Mixed vegetables & 33.178 & 34.187 & $3 \%$ \\
\hline Endive & 26.788 & 27.210 & $2 \%$ \\
Mix for noodles and rice & 25.695 & 26.269 & $2 \%$ \\
\hline Carrots & 26.275 & 25.923 & $-1 \%$ \\
\hline Macaroni/spaghetti veg. & 19.785 & 21.149 & $7 \%$ \\
\hline String beans & 15.806 & 17.741 & $12 \%$ \\
\hline Kale & 15.192 & 16.856 & $11 \%$ \\
\hline Total & $\mathbf{5 9 4 . 2 7 9}$ & $\mathbf{6 3 1 . 1 5 8}$ & $\mathbf{6 \%}$ \\
\hline
\end{tabular}

Source: PT / Nielsen

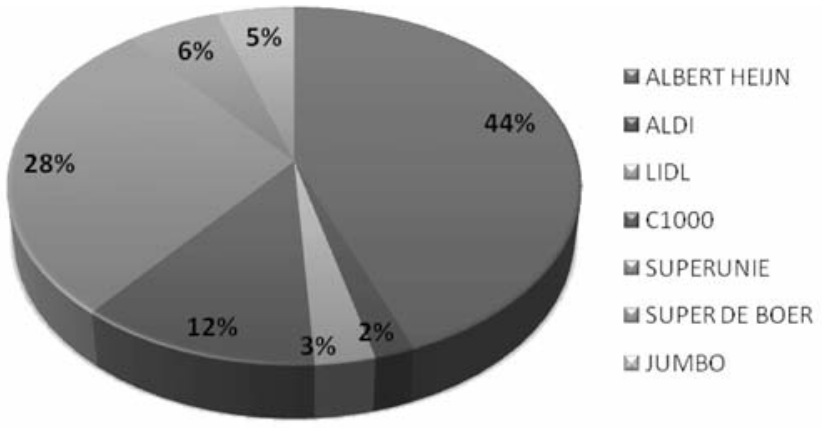

Figure 3. Supermarket sales of pre-treated fresh vegetables in 2010 (value) Source: PT / Nielsen

Remarkable is the large share of Albert Heijn in the sales of pre-treated fresh vegetables. More than $44 \%$ of the total supermarket sales of pre-treated fresh vegetables is in the hands of Albert Heijn. In particular Aldi has a very small share of the pre-treated vegetables. The differences in assortment in the supermarket chains is significant. The research bureau Nielsen has measured the turnover of 47 different kinds of pre-treated vegetables. 40 products are available at Albert Heijn. 35 and 36 respectively at C1000 and Super de Boer. In Lidl and Aldi are respectively 13 and 9 products available.

\section{Canned vegetables}

Consumers in Holland have bought for $€ 210$ million canned vegetables in supermarkets. This was $2 \%$ less than in 2009. Although beans are still the most bought canned vegetable, the turnover went down with $9 \%$. Also the other most important vegetables went down between $0 \%$ and $5 \%$. Most positive is the turnover from corn with an increase of $4 \%$. This is due to the fact that "international" dishes are very popular in Holland.

Table 8. Supermarket sales canned vegetables ( €× 1000)

\begin{tabular}{lrrr}
\hline & $\mathbf{2 0 0 9}$ & $\mathbf{2 0 1 0}$ & $\begin{array}{c}\mathbf{2 0 1 0} \\
\mathbf{2 0 0 9}\end{array}$ \\
\hline Green beans & 26.124 & 23.681 & $-9 \%$ \\
\hline Peas and Carrots & 23.358 & 23.375 & $0 \%$ \\
\hline Peas & 19.708 & 18.642 & $-5 \%$ \\
\hline Red cabbage & 17.903 & 17.454 & $-3 \%$ \\
\hline Brown beans & 16.866 & 16.944 & $0 \%$ \\
\hline Corn & 12.788 & 13.287 & $4 \%$ \\
\hline White beans & 9.861 & 9.962 & $1 \%$ \\
Carrots & 7.100 & 7.147 & $1 \%$ \\
\hline Beetroot & 7.163 & 7.025 & $-2 \%$ \\
\hline Muchrooms & 8.777 & 7.002 & $-20 \%$ \\
\hline Totaal & $\mathbf{2 0 1 . 3 7 4}$ & $\mathbf{1 9 7 . 2 1 6}$ & $\mathbf{- 2 \%}$ \\
\hline
\end{tabular}

Source: PT / Nielsen

Albert Heijn is very strong in fresh vegetables. Remarkable therefore is the strong position of Superunie in the sales of canned vegetables. Superunie has a share of almost $35 \%$ in 2010 and this share is still increasing.

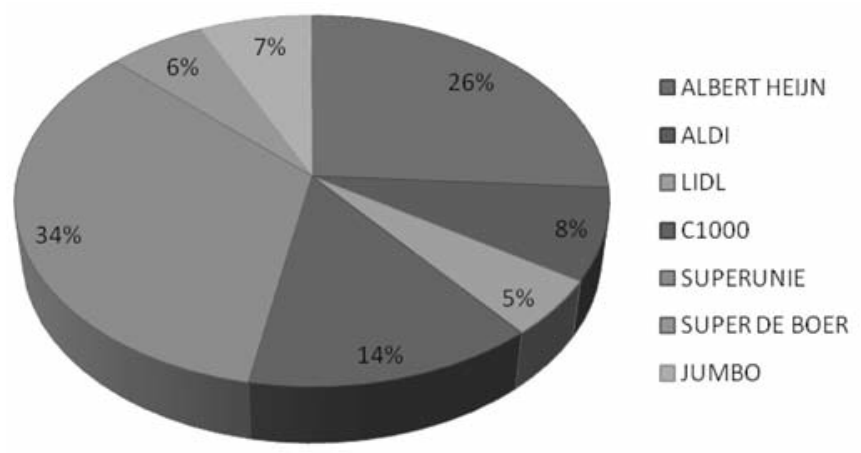

Figuur 4. Supermarket sales of canned vegetables (value) Source: PT / Nielsen

\section{Frozen vegetables}

Compared with the sales of fresh products, the group of frozen vegetables is relatively small. The turnover of almost 68 million Euros is achieved by the sale of over 31 million $\mathrm{kg}$ of products. After a number of years of decreasing, the sales 
increase in 2010 with $5 \%$ overall. Far out the most important product is spinach with a share of more than $40 \%$. Sales of frozen spinach is increasing with $10 \%$ in 2010. Other vegetables with considerable growth of $10 \%$ to $30 \%$ are beans, peas, kale and broccoli.

Table 9. Supermarket sales frozen vegetables ( €× 1000)

\begin{tabular}{|c|c|c|c|}
\hline & 2009 & 2010 & $\begin{array}{l}2010 \\
/ \\
2009\end{array}$ \\
\hline 1. Spinach & 25.271 & 27.779 & $10 \%$ \\
\hline 2. Vegetable dishes & 6.674 & 5.972 & $-11 \%$ \\
\hline 3. Mixed vegetables & 5.445 & 5.023 & $-8 \%$ \\
\hline 4. Green beans & 4.133 & 4.709 & $14 \%$ \\
\hline 5. Red cabbage & 4.390 & 4.271 & $-3 \%$ \\
\hline 6. Garden peas & 2.805 & 3.086 & $10 \%$ \\
\hline 7. Peas & 1.722 & 2.217 & $29 \%$ \\
\hline 8. Cauliflower & 1.490 & 1.958 & $31 \%$ \\
\hline 9. Kale & 2.126 & 1.945 & $-9 \%$ \\
\hline 10. Broccoli & 1.213 & 1.493 & $23 \%$ \\
\hline Total & 64.372 & 67.906 & $5 \%$ \\
\hline
\end{tabular}

Source: PT / Nielsen

Just as with the canned vegetables, Superunie has also with the frozen foods a large share. With $31 \%$, Superunie almost has the same position as Albert Heijn. Also the share of frozen vegetables of discounters is less than their overall market share.

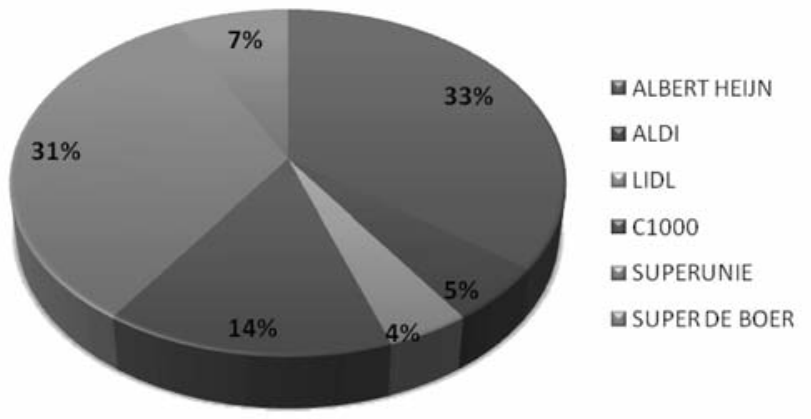

Figure 5. Supermarket sales of frozen vegetables (value) Source: PT / Nielsen

\section{Supermarket Sales of fruit}

The turnover of supermarkets for fruit is growing in 2010 with $3 \%$ in value. As many as $93 \%$ of the turnover is accounted for by fresh unprocessed fruit. The turnover of fresh sliced fruit is increasing with $17 \%$, but was in 2010 still not more than $3 \%$ of the total turnover of fruit in supermarkets. The share of frozen fruit is with $€ 5,5$ million very modest, but it is increasing with $26 \%$. Just as with the vegetables is the turnover of canned fruit decreasing. In 2010 the turnover fell, with $6 \%$ compared with 2009 , below $€ 50$ million.

The supermarket is the main sales channel for fresh fruit. More than $75 \%$ of the consumer spending on fresh fruit is spent in the supermarket. The share of the supermarkets is still increasing. In 2010, the growth of fresh fruit in the
Table 10. Supermarket sales of fruit ( €x 1000)

\begin{tabular}{lrrr} 
& $\mathbf{2 0 0 9}$ & $\mathbf{2 0 1 0}$ & $\begin{array}{c}\mathbf{2 0 1 0} \\
/\end{array}$ \\
& & & $\mathbf{2 0 0 9}$ \\
\hline Fresh & 1.129 .847 & 1.161 .892 & $3 \%$ \\
Pre-treated & 29.817 & 34.739 & $17 \%$ \\
Canned & 53.042 & 49.858 & $-6 \%$ \\
Frozen & 4.323 & 5.444 & $26 \%$ \\
\hline Total & $\mathbf{1 . 2 1 7 . 0 2 9}$ & $\mathbf{1 . 2 5 1 . 9 3 3}$ & $\mathbf{3 \%}$ \\
\hline
\end{tabular}

Source: PT / Nielsen

supermarket was $3 \%$ and the growth of the total fruit market was only $0.3 \%$. Fruit is relatively often sold pre-packed. In 2010 almost half (47\%) of the fruit was sold pre-packed in nets, bags, on trays and so on.

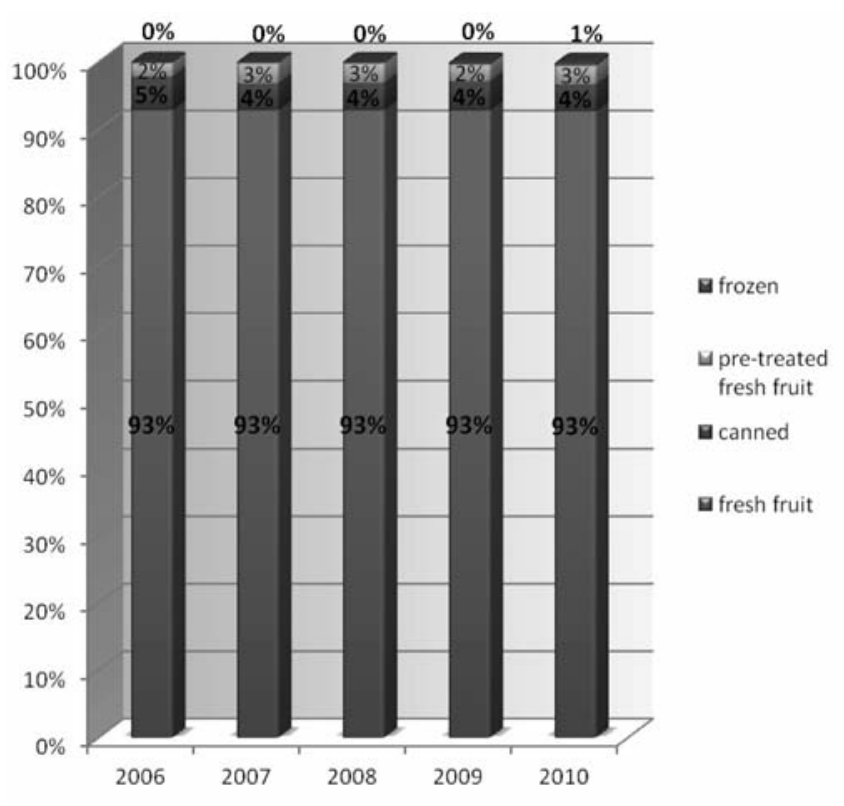

Figure 6. Supermarket Sales fruit (value)

Source: PT / Nielsen

\section{Fruit in supermarkets chains}

Albert Heijn was 2010 the supermarket chain who sold next to the fresh unprocessed fruit the largest amount of fresh pre-treated fruit. The share of fresh pre-treated fruit is increasing but still not comparable with the share of fresh pre-treated vegetables.

Both discounters Lidl and Aldi have a relatively high share of canned food. Super de Boer and C1000 in terms of market share of canned fruit, take position between Albert Heijn and the discounters. Remarkable is the position of Aldi. Aldi is in terms of market positioning completely the opposite of Albert Heijn. Aldi is a real discounter while Albert Heijn is in the top segment of the supermarket chains. However in the category of pre-treated fresh fruit with a relative high value, Aldi is the only supermarket chain who can almost achieve the same share in sales as Albert Heijn. Albert Heijn is in general relatively strong in the sales of fresh products. Also the market share of fresh fruit is no 


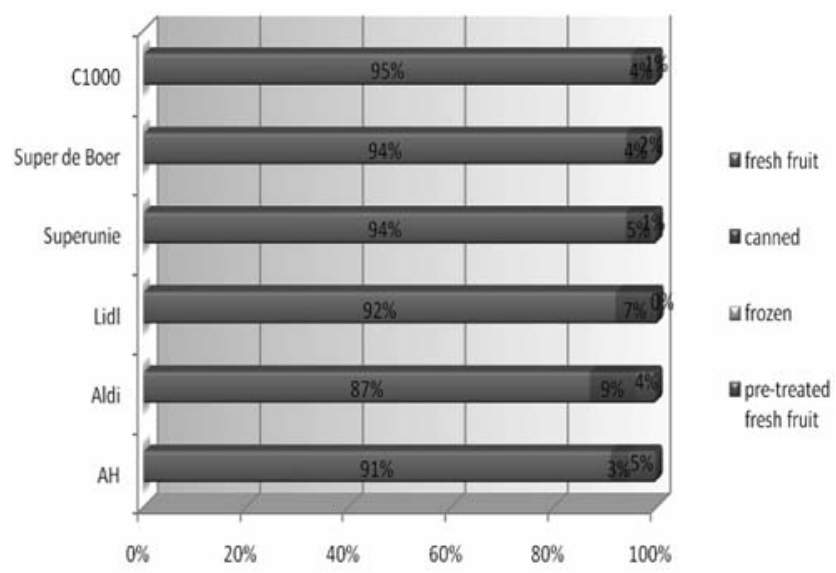

Figure 7. Fruit in supermarket chains in 2010 (value) Source: PT / Nielsen

exception and is higher than the overall market share of Albert Heijn. Aldi however scores with fresh fruit lower than their overall market share. In the other chains, the market share of fresh fruit has a similar level as the overall market share.

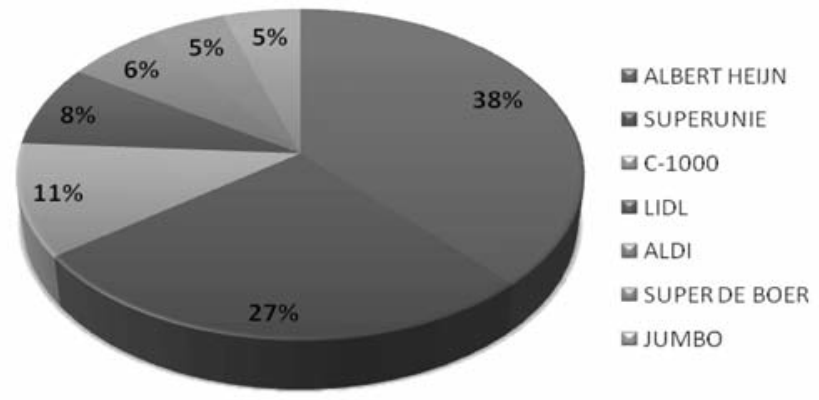

Figure 8. Supermarket Sales of fresh fruit in 2010 (value) Source: PT / Nielsen

\section{Pre-treated fresh fruit}

Pre-treated fresh fruit is mostly washed and sliced fruit. It is still a small category with a limited assortment. Although the category is now growing considerably. The value of this segment has grown $17 \%$ to almost $€ 35$ million in 2010 . The mixed fruit salad is the most important product in this segment, but the exotics among which are mango and pineapple are increasing very fast.

Table 11. Supermarket Sales for pre-treated fresh fruit $€ \times 1000)$

\begin{tabular}{lrrr}
\hline & $\mathbf{2 0 0 9}$ & $\mathbf{2 0 1 0}$ & $\begin{array}{c}\mathbf{2 0 1 0} \\
/\end{array}$ \\
& & & $\mathbf{2 0 0 9}$ \\
\hline Mixed & 11.475 & 13.608 & $19 \%$ \\
Exotic fruits & 8.511 & 10.247 & $20 \%$ \\
Melons & 6.542 & 7.004 & $7 \%$ \\
Pears & 2.419 & 2.589 & $7 \%$ \\
\hline Apples & 682 & 826 & $21 \%$ \\
Soft fruits & 183 & 459 & ++ \\
\hline Total & $\mathbf{2 9 . 8 1 7}$ & $\mathbf{3 4 . 7 3 9}$ & $\mathbf{1 7 \%}$ \\
\hline
\end{tabular}

Source: PT / Nielsen
Remarkable is the huge market share in pre-treated fresh fruit of Albert Heijn. More than 70\% of this market segment is in the hands of Albert Heijn. All the other chains achieve market shares that are significantly below their overall market share.

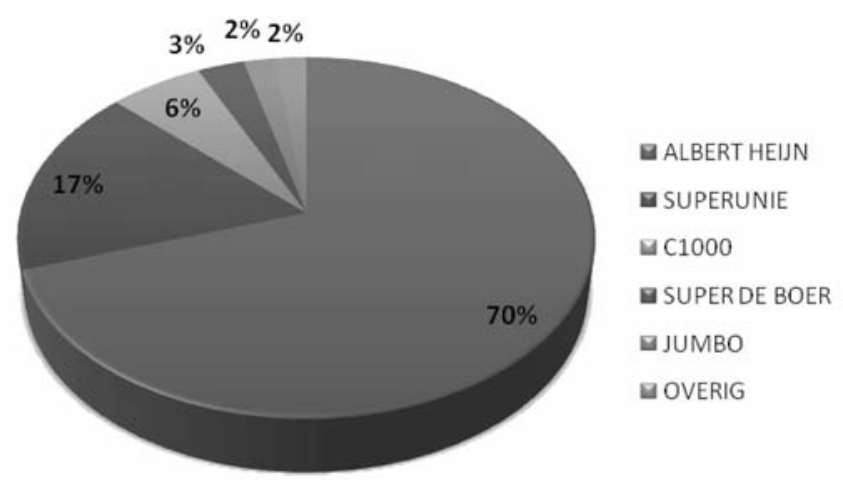

Figure 9. Supermarket Sales for pre-treated fresh fruit in 2010 (value) Source: PT / Nielsen

\section{Canned fruit}

The market for canned fruit was a fairly constant segment for a long period, but in 2010 this market segment went down with $6 \%$ to just under $€ 0$ million. The main product in this category is pineapple, followed by fruit cocktail and peach. The fact that fresh fruit salads and canned fruit cocktail are complementary is clearly visible in table 11 and 12 . Canned fruit cocktail is decreasing, while the mixed fresh fruit salads are becoming more popular.

Table 12. Supermarket Sales canned fruit (€x 1000)

\begin{tabular}{lrrr}
\hline & $\mathbf{2 0 0 9}$ & $\mathbf{2 0 1 0}$ & $\begin{array}{c}\mathbf{2 0 1 0} \\
/ \\
\mathbf{2 0 0 9}\end{array}$ \\
\hline 1. Pine apple & 15.836 & 15.108 & $-5 \%$ \\
2. Fruitcocktail & 10.450 & 9.482 & $-9 \%$ \\
3. Peach & 9.364 & 8.761 & $-6 \%$ \\
4. Cherry & 3.819 & 4.132 & $\mathbf{8} \%$ \\
5. Pear & 3.125 & 3.159 & $1 \%$ \\
6. Mandarine & 2.818 & 2.073 & $-26 \%$ \\
7. Pie filling & 2.644 & 1.953 & $-26 \%$ \\
8. Strawberry & 980 & 1.288 & $31 \%$ \\
9. Mixed fruits & 427 & 683 & $60 \%$ \\
10. Forrest fruits & 499 & 669 & $34 \%$ \\
\hline \multicolumn{1}{c}{ Total } & $\mathbf{5 3 . 0 4 2}$ & $\mathbf{4 9 . 8 5 8}$ & $\mathbf{- 6 \%}$ \\
\hline
\end{tabular}

Source: PT / Nielsen

It is obvious that Albert Heijn aims strongly on the fresh fruit market and less on the canned fruit market. Their market share is with $29 \%$ relatively small. The discounters however, have remarkable large market share in this segment. They achieve this market share with a relatively small assortment. However canned fruit in the service supermarkets is considerably more expensive than in the two discounters. This has two reasons. First of all the service supermarkets have a more exclusive assortment with more expensive products. Furthermore, similar products in service supermarkets are more expensive than in the discounters. 


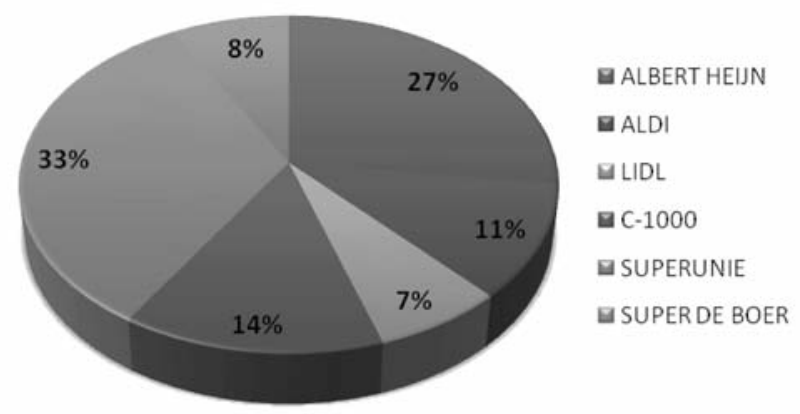

Figure 10. Supermarket sales of canned fruit in 2010 (value) Source: PT / Nielsen

\section{Frozen Fruit}

With a total value of $€ 5,5$ million, frozen fruit is the smallest fruit category. Raspberries are the most important item with a market share of almost $50 \%$ of the total value. In addition, the raspberry achieves a considerable increase in turnover over the past two years. Also fruit mix and dessert fruit are increasing articles. Tropical fruit is often used in these articles. This explains the decrease of tropical fruit.

Albert Heijn is the undisputed leader in this segment of the market. $81 \%$ of the sales is done by Albert Heijn. With

Table 13. Supermarket sales frozen fruit ( €x 1000)

\begin{tabular}{|rlrrr}
\hline & & $\mathbf{2 0 0 9}$ & $\mathbf{2 0 1 0}$ & $\begin{array}{c}\mathbf{2 0 1 0} \\
/ \\
\mathbf{2 0 0 9}\end{array}$ \\
\hline $\mathbf{1}$ & Raspberry & $\mathbf{1 . 8 9 6}$ & $\mathbf{2 . 5 9 0}$ & $\mathbf{3 7 \%}$ \\
\hline $\mathbf{2}$ & Blueberries & 996 & 1.035 & $4 \%$ \\
\hline $\mathbf{3}$ & Summer fruit & 1.005 & 1.010 & $1 \%$ \\
\hline $\mathbf{4}$ & Fruit mix & 90 & 399 & $343 \%$ \\
\hline $\mathbf{5}$ & Dessert fruit & 0 & 327 & - \\
\hline $\mathbf{6}$ & Fruit salad & 22 & 39 & $80 \%$ \\
\hline $\mathbf{7}$ & Tropical fruit & 292 & 21 & $\mathbf{- 9 2 \%}$ \\
\hline $\mathbf{8}$ & Strawberries & 19 & 20 & $\mathbf{7} \%$ \\
\hline & Total & $\mathbf{4 . 3 2 3}$ & $\mathbf{5 . 4 4 4}$ & $\mathbf{2 6 \%}$ \\
\hline
\end{tabular}

Source: PT / Nielsen

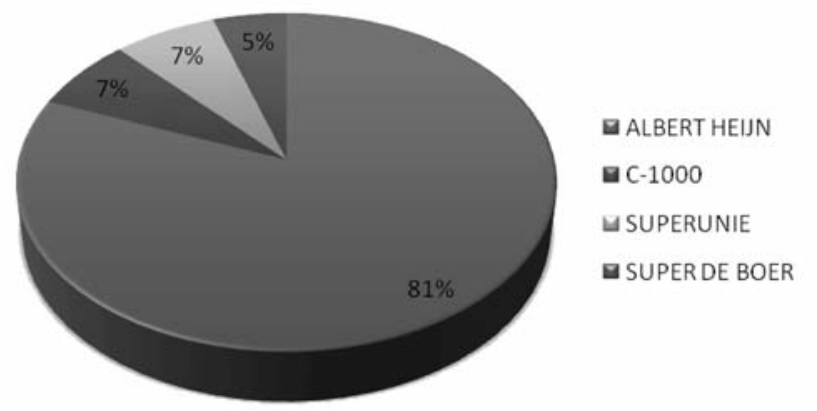

Figure 11 Supermarket Sell frozen vegetables in 2010 (value) Source: PT / Nielsen such a large market share, it is not surprising that the main products at Albert Heijn also the leading products in the market. In figure 14 the two discounters are missing, because there is no registration of frozen products in the Aldi and Lidl.

\section{Consumer Trends}

\section{Consumption of fruit and vegetables}

To analyze the developments and trends of fruit and vegetables, continuous research is necessary. Consumer behaviour concerning the use of fruit and vegetables keeps changing. From the results of the present research we can conclude the following, which applies specifically for the younger people (20-35 years).

- There is a relatively high degree of awareness regarding the "must' to use enough fruit and vegetables. This is also influenced by the more general trends towards healthy eating habits and an intensive campaign to promote the eating of fruit and vegetables.

- This does not mean that this awareness automatically is translated into concrete changes of behaviour. In this respect, there are a number of barriers to break down. They have mainly to do with the perception that vegetables are "not easy", a lack of cooking skills and knowledge. Also because people often choose for convenience and speed. The latter not only because people would be more 'easy', but also because of the current 'Busy' lifestyles of young people and young families: the need for convenience is for an important part situational determined.

This mentioned developments have important implications for the supply situation. The impression is that they are insufficiently responsive to consumer needs when it comes to convenience solutions regarding fruit and especially vegetables. Even though the supply of pre-treated fruit and vegetable combinations in recent years has grown, the market appears not at all saturated and is not yet finished developing. There seems insufficient attention in the shops to make clear how the consumer should prepare unknown vegetables, or how well-known vegetables can be prepared in another way than the tradition prescribes. Given the fact that consumer requirements are changing, this an important issue. Some companies step into this trends by introducing concepts in the market which offer this "variation" and "easy to prepare". For the vegetable sector, it is important to take action and develop more initiatives.

\section{Fruit and vegetables as healthy snack}

The 'in between use' of food in the form of snacks now day's become a common habit. In particular the feeling of the 4 o'clock moment, but also the 11 o'clock moment are often moments of a desire to eat something. Reason for this is not necessarily an empty feeling but it can also be the need for 
energy. Research shows that fruit and vegetables are gaining in popularity to fulfil the urge to eat something. Health is mostly the moving force to use fruit and vegetables as an in between snack. Especially if people are trying to lose weight, but also in general more and more people use a healthy instead of an unhealthy snack. However there is still a lot to do for the sector. In particular, the condition 'convenience' needs to be taken care of. The introduction of spray tomatoes, carrot balls or a bowl of raw mixed salad are to limited. In fact, here is an important task for concept and product development.

The need for tasty, yet quick and easy meals requires quick cooking methods. Stir baking, but also steaming vegetables is an important cooking solution. This kind of new habits and methods not only gives promotional opportunities, but also opportunities for further concept and product development.

\section{The use of recipes}

Research shows that people, especially younger people, use less and less recipes while preparing a meal. Culinary cookers are the only exception. They anyway prefer to inform themselves better about food and the way to use it. They often use recipes for inspiration, but are fond of changing it to own ideas and taste.

Ordinary people who are characterized by the standard repertoire in cooking hardly use recipes, although they have a need for variation and want to have information about it. They want to use new vegetables, try new cooking methods and new recipes. However they have to be strongly confronted with it. They are hardly looking for new inspiration themselves. If they own cooking books, they hardly use them. Also the recipe cards from supermarkets are hardly used, because they are to much trouble or complicated. Demonstrations at point of sale in the shops however are very effective to show how easy it can be to prepare new vegetables or to use new recipes.

\section{Key meanings of fruit and vegetables}

The way people in general see food now day's has important consequences for perception of fruit and vegetables and the place it takes in the daily life. The following items are central to the perception of food:

- Good taste, enjoy

- Convenience (preparation)

- Health

A key value is also "care" for yourself or for others. This key value is closely linked to the item enjoy and health and therefore in this contexts will be discussed. An explanation of these comprehensions is shown below.

\section{Good taste and enjoy fruit and vegetables}

The fact that food tastes good is for everybody a condition for purchase. Sometimes, however, concessions are made because of health. This applies in particularly for the use of vegetables. Vegetables can be seen as an integral part of the meal when it comes to healthy feelings. Although there are many people who appreciate vegetables as they are, we often see that vegetables need an extra boost to be found tasty:

- By use of sauces, spices, dressings, etc.

- The processing of vegetables in dishes, based on rice, pasta, etc.

- By making a mix of vegetables, meal salads, etc.

An important condition to keep liking certain food is variation. Always the same dish on the table will be boring. People also sometimes want to surprise the family with something new. Here we are dealing with an important problem, especially with ordinary people who are characterized by the standard repertoire in cooking. They do not have enough skills, and experience in technology and creativity to provide enough variation.

\section{Speed and convenience in preparation of fruit and vegetables}

For most people convenience and speed of preparation of food are important conditions for purchasing this food. The need for convenience and speed for an important part depends on the situation. People often have little time to give attention to prepare a meal. Now day's a growing amount of people can be characterized as individuals whose career is important for them with busy jobs, a rich social life and combining work and children. Those people are pleased with convenience food solutions.

\section{Health}

When people get older and are going into and a new life stage, health gets increasingly more important. This has influence on the choice for food. The perception of 'health' has different aspects:

- Nutritional:

To get enough of the right nutrients and vitamins. In this respect, the rule which is promoted in Holland of 200 grams vegetables +2 pieces of fruit per day is important. This rule seems generally to be handled, although not very accurate kept. It often appears there that this rule is not kept because of a lack of time, especially when it comes to eating enough vegetables. People try to find a balance for any 'shortage' by eating extra healthy on the next day.

- To be fit / to feel fit:

"Healthy" food contributes to a fit and healthy feeling, both physically and mentally. People feel better in terms of "doing good". Vegetables have in this respect as a healthy product an important, but also very general role. This also applies to fruit, which more often has a specific link to resistance and energy.

- Weight control:

To reach a certain weight or maintain a proper weight 
also has healthy consequences. We look more attractive to others, but also to our self ( "happy with yourself "). Fruit and vegetables play in this context an important role, because eating something healthy prevents eating something unhealthy as sweets, snacks etc.

- Health / growth of children:

Fruit and vegetables are seen as important products for the growth and development of children. If children do not eat fruit and vegetables very well, parents really can get worried. Fruit and vegetables are seen as suppliers of body-building nutrients and vitamins. But also from educational perspective parents often have the opinion that children should (learn to) eat fruit and vegetables.

\section{References}

Angus Deaton, John Muellbauer (1980): Economics and consumer behaviour, Cambridge University Press

Bunte, F.H.J. (2009): Glasstuinbouw groener met emissiehandel, Kennis Online 6 (jan.) p.12.

CBS (1999-2010) : Jaarverslag groenten en fruit

EUROSTAT (1999-2010) : Statistical information

Ministerie van VWS (2008): Campagne Schoolgruiten
Ministerie van VWS (2006): Nieuwe richtlijn vezelconsumptie

Mowat, A.D, Collins, R.J. (1997): Modeling consumer buying behavior to fruit quality, Proceedings of the Australasian PostHarvest Conference, University of Western Sydney, Hawkesbury, 111-114.

J.Paul Peter, Jerry C. Olson (2001) Consumer Behavior and Marketing Strategy, Lavoisier

PT (2010) : Aankoopgedrag in Nederland /Gekochte verse groente en fruit in Nederland

PT (2006/2010): Aankopen van verse groenten en fruit door Nederlandse Huishoudens

PT (2007) : Barriéres groenten en fruit consumptie

PT (2008): EU-Nieuws 12: Europese Schoolfruit Campagne

\section{Internetes adatforrások}

CBS: http://cbs.nl

ENSZ: http://unstats.un.org/unsd/comtrade

FAO:

http://faostat.fao.org/faostat/collections?subset=agriculture

PT: http://tuinbouw.nl

GFK: http://www.gfk.com

Nielsen: http://nl.nielsen.com 